\title{
Snow storage - Modelling, theory and some new research
}

\author{
Nina Lintzén*, Sven Knutsson \\ Luleå University of Technology, SE-971 87 Luleå, Sweden
}

\begin{abstract}
A B S T R A C T
The arrival of natural snow is often delayed nowadays due to global warming. This causes problems for ski resorts and other places where winter activities in different forms take place. Storing snow provides one solution for the winter business industry to deal with this problem. However, there is so far very little research concerning this question. In this paper a review of current knowledge of snow storage and experiences from mainly Scandinavian snow storages is presented. New results concerning melting losses of stored snow from a trial experiment in the north of Sweden are presented. These results are compared to theoretical calculations. The model used for the calculations is shown to be useful for estimating melting losses of insulated piles of snow. Thus the calculations can serve as an important background when designing an insulated snow depot. The model can also be used to compare different insulating materials and to determine properties such as thickness of the insulating layer needed to sufficiently insulate the snow. By minimizing the surface area of insulated snow depots, melt rate due to heat from the air, sun and sky, which constitute the largest part of the total melt, can be reduced. The quality of insulating materials used will be subject to annual observation. Commonly used insulating materials such as bark, wood chips, cutter shavings and sawdust deteriorate.
\end{abstract}

\section{Introduction}

Storage of snow is an old technique which was common for food storage applications before refrigerators were developed at the beginning of the 20th century (Skogsberg, 2005). Skogsberg and Nordell (2001) mention for instance himuros and yukimoros, which are houses or rooms where vegetables are stored together with ice or snow in order to maintain their quality. Nowadays snow and ice are stored for different purposes. Japan, China, Canada, USA and Sweden are some countries where different techniques of snow and ice storage for cooling applications have been performed (Nordell and Skogsberg, 2007; Kumar et al., 2016). The hospital in Sundsvall, Sweden, is one example where snow has been stored for cooling purposes (Skogsberg, 2001). Utilizing snow and ice for cooling is according to Nordell and Skogsberg (2007) a renewable natural energy without any environmental drawbacks.

An enhanced interest in storing snow for winter activities has been observed during the last decade. Due to global warming, the arrival of natural snow has become more unpredictable and at the same time higher temperatures imply difficulties with traditional snow making. Storing snow in order to guarantee an early start of the season has become more common for establishing cross country ski tracks, alpine ski slopes and ski jumping areas. A stored snow depot enables resorts and skiing facilities to guarantee a fixed opening date. Stored snow is also used for summer ski events. The typical size for a snow depot is $5000-30,000 \mathrm{~m}^{3}$, although they may also be larger (Martikainen, 2016). According to Martikainen (2016) the first insulated snow storage in the world specifically for skiing was located in Ruka, Finland in 2000. Different types of insulating materials, such as sawdust, foamed plastics, aluminum foil, geotextiles and sheets with different properties have been used to insulate stored snow. Both natural and machinemade snow can be stored, although machine-made snow is more common when storing snow for winter activities since it is considered more durable and weather resistant than natural snow (Rixen et al., 2003, 2004 and others).

Snow can be stored indoors in a thermally insulated building, underground in a cavern in which case no insulation is necessary, or on the ground in open ponds or pits. Snow stored on the ground covered with some kind of insulating material is the most common method (Nordell and Skogsberg, 2007). The thermal insulating material can be either natural materials or fabricated materials. There are different methods for insulating open pond snow storages, i.e. piles of snow which are stored on the ground. Martikainen (2016) distinguishes between three different methods; a breathable method, which means an insulating material which enables evaporation, a non-breathable method, which is an insulating material which only insulates the snow, or a combination of the two methods. Most common in Scandinavia seems to be a breathable method with a natural insulating material.

\footnotetext{
* Corresponding author.

E-mail addresses: nina.lintzen@ltu.se (N. Lintzén), sven.knutsson@ltu.se (S. Knutsson).
} 
Table 1

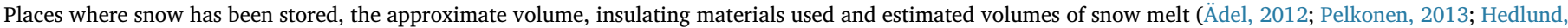
2016; Martikainen, 2016; Rindal, 2016; Rommedahl, 2016).

\begin{tabular}{|c|c|c|c|}
\hline Place & Volume $\left[\mathrm{m}^{3}\right]$ & Cover material & Estimated total snow melt[\%] \\
\hline Vuokatti, Finland & $20,000-25,000$ & Tarpaulin and Sawdust, $30-40 \mathrm{~cm}$ & 20 \\
\hline Östersund, Sweden (2006) & 2 piles $-10,000$ & Sawdust, $\approx 70-80 \mathrm{~cm}$ & 30 \\
\hline Östersund, Sweden & 20,000 & Sawdust, $\approx 50 \mathrm{~cm}$ & 20 \\
\hline Östersund, Sweden (2015) & 30,000 & Sawdust, $\approx 40 \mathrm{~cm}$ & 12 \\
\hline Orsa, Sweden & 5000 & Bark, $\approx 40-50 \mathrm{~cm}$ & - \\
\hline Högbo Bruk, Sweden & 8000 & Sawdust & - \\
\hline Piteå, Sweden (2012) & 2400 & Geotextile, Bark, $\approx 50-70 \mathrm{~cm}$, partly covered with plastics & 29 \\
\hline Piteå, Sweden (2013) & 3400 & Geotextile and Bark, $\approx 50-60 \mathrm{~cm}$ & 29 \\
\hline Arjeplog, Sweden (2013) & 1600 & Geotextile and Bark, $\approx 40-50 \mathrm{~cm}$ & 61 \\
\hline Sochi, Russia (2013) & 800,000 (several piles) & Geotextile in several layers, foamed plastics, aluminum foil & $20-50$ \\
\hline Birkebeiner Ski Stadium, Norway & 40,000 & Wood chips, $\approx 30-50 \mathrm{~cm}$ & ca. 17 \\
\hline
\end{tabular}

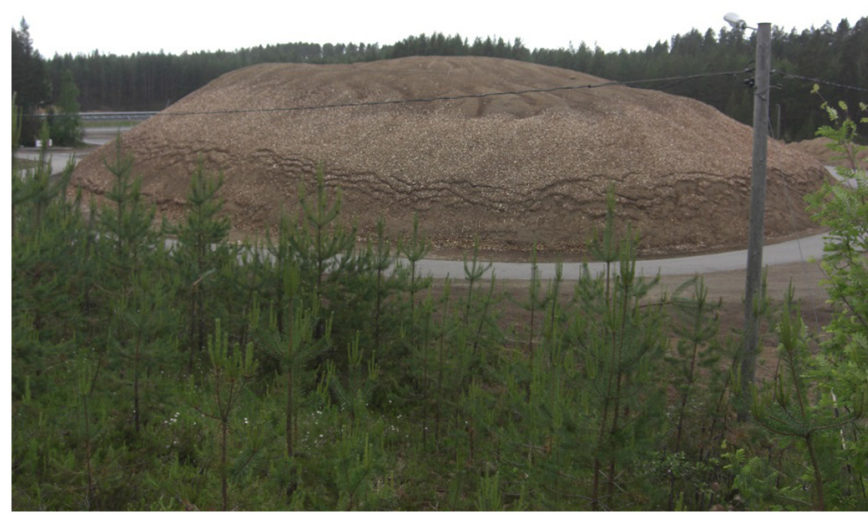

Fig. 1. Snow storage (about $25,000 \mathrm{~m}^{3}$ ) insulated with sawdust, Vuokatti, Finland, 2013.

Table 1 shows a compilation of information from some places where snow has been stored together with the insulating materials used. Natural insulating materials are, for example, bark, crop residues such as rice husks, mineral particles or debris and different types of wood chips, which here include cutter shavings of different sizes, sawdust and wood powder. Fabricated materials are generally different kinds of loose sheets, such as plastic sheets, filled tarpaulins (e.g. with straw), geotextile sheets, aluminum foil, felts and sometimes thermal foam in between (Skogsberg, 2005; Martikainen, 2016). The most commonly used insulating materials for snow storages in Scandinavia are bark and different types of cutter shavings. As an example, a pile of stored snow covered with sawdust is shown in Fig. 1.

According to Martikainen (2016) a snow depot should be associated both with low environmental impact and snow available at a low cost. Therefore, many local factors at the place where the snow is supposed to be stored need to be taken into account in order to optimize the snow depot.

There are many different factors which affect the melting rate of an insulated snow depot. Skogsberg (2005) categorises snow melting in warm surroundings as natural melt and divides it into three parts; ground melt, surface melt and rain melt, see Fig. 2. Ground melt is due to heat transfer through the bottom of a pile placed on the ground. Surface melt occurs by heat transfer from the air, sun and sky. Rain melt is melting caused by rain seeping through the insulation to the snow. Surface melt is, according to Skogsberg (2005), the major factor influencing the total melt rate. The climate, the choice of thermal insulation and the geometry of the snow pile are factors affecting the melting rate (Nordell and Skogsberg, 2002).

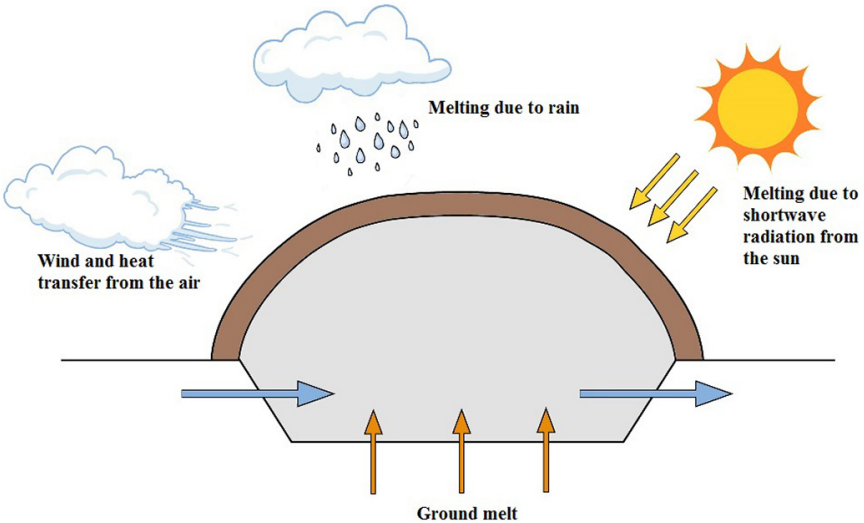

Fig. 2. Factors affecting the melting rate of an insulated pile of snow are ground melt which is due to heat transfer through the ground, surface melt which includes heat transfer from the air, sun and sky and rain melt (Modified after Skogsberg, 2005).

The optimum design for snow storage is not yet fully understood. The objective of this paper is to review and summarize current knowledge and experiences from some places where snow has been stored and to present new results from practical experiments of snow storages. Furthermore, a theoretical model is retrieved for theoretically estimating melting losses of insulated snow depots. Results from theoretical calculations are compared to the practical experiments. The calculated results of melting losses prove to agree well with measured values, showing that such a model can be useful when designing snow storages. Theoretical calculations can be used for choosing the geometry of the pile, type and amount of insulating material needed and for determining the initial amount of snow needed in order to preserve the desired amount for the upcoming winter season.

\section{Knowledge regarding snow storage}

\subsection{Mass and heat transfer in an insulated snow depot}

The mass and heat transfer through a porous material used as thermal insulation for a snow depot placed on the ground, occurs through water transport, heat conduction, heat convection and radiation (Skogsberg and Lundberg, 2005). This is illustrated in Fig. 3. The radiation exchange at the surface of the insulating layer includes both short wave radiation from the sun and long wave radiation, i.e. heat. The convective heat and mass transfer is according to Skogsberg and Lundberg (2005) influenced by the temperature, humidity, wind velocity and the properties of the insulating layer such as surface roughness of the material, water transport capacity and compaction. The thermal conductivity depends on the properties of the insulating material, such as structure, density and moisture content. The energy conduction rate 


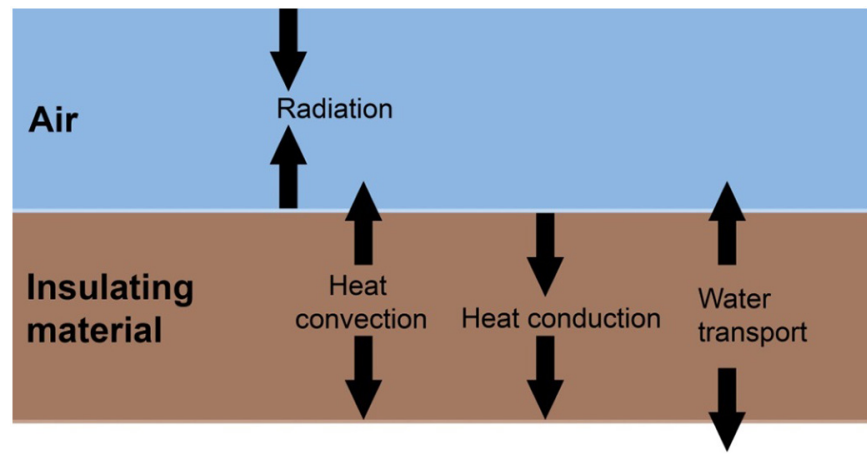

\section{Snow}

Fig. 3. Mass and heat transfer through a porous material (Modified after Skogsberg and Lundberg, 2005).

depends on the temperature difference between the different media.

Moisture is transported as vapour and as water (Skogsberg, 2005). Vapour is transferred by diffusion and by mass convection. Water is transferred by Darcy flow and by suction. Most of the melt water is transported downwards through the snow. In wood chip layers, some of the water is transported upwards, through the insulating layer due to capillary forces and evaporation. Evaporation requires energy and will therefore cool the insulating layer and thereby decrease the melt rate. Evaporation is, according to Skogsberg and Lundberg (2005), a minor part in the mass balance but plays a significant role in the energy balance. This is due to the latent heat. The latent heat of vaporization, i.e. when a liquid becomes gas, is 7.5 times greater than the latent heat of fusion, i.e. when a solid becomes liquid. Thus even minor evaporation will decrease the melt rate significantly.

The natural melting of an insulated snow depot was divided into surface melt, rain melt and ground melt by Skogsberg (2005), of which surface melt constituted the largest part of the total melt. Studies made by Skogsberg and Lundberg (2005) showed that the melt rate decreased with increased thickness of the insulating layer. The melt rate increased with wind velocity, long wave and short wave radiation, air temperature and air humidity. Moreover, they found that the evaporative cooling effect was important and that the melt rate drastically increased without evaporation. These parameters have a great impact on the snow melt and are important in the overall energy balance.

\subsection{Thermal insulation and practical examples of snow storages}

The choice of thermal insulating material will affect the melt rate. In Scandinavia, wood based materials such as bark, sawdust and wood chips are commonly used as shown in Table 1. One drawback with wood based materials as thermal insulation is the degradation with time (Skogsberg, 2005). The material darkens with age, thus absorbing a higher portion of shortwave radiation which together with deterioration of water transport reduces the insulating capacity. New, unused geotextiles have also been found to have higher values of shortwave reflectivity than used geotextiles (Olefs and Fischer, 2008). Thus also fabricated materials appear to become impaired with time.

Information from places where snow has been stored outdoors was collected in order to summarize information and to compare experiences and methods. The volume of snow depots, the insulating material used and the approximate melted volume, where this was known, are shown in Table 1. The approximate period of storage was from late spring until the end of October/early November. In Sochi, Russia, snow was stored to be used in February for the Olympic Games. The pile in Arjeplog consisted of natural snow and the piles in Piteå were a mix of natural snow and machine made snow, which was scraped together from a nearby ski slope when it closed for the season. All other piles consisted of machine-made snow.

In the Finnish city Vuokatti, snow has been stored for more than 10 years to construct cross country ski tracks (Pelkonen, 2013). Each year on the 10th of October the outdoor ski track of stored snow opens, in connection with an indoor track in a ski tunnel. This prolongs the pre-season by 1-2 months and has become a successful business since it enables professional athletes to carry out their pre-season training. The estimated melted volume of snow during the period of storage is $20 \%$.

Östersund in Sweden has been storing snow since 2006 (Hedlund, 2016). The stored snow is of importance for the city since they annually host the world cup opening with the biathlon. The stored snow is used each year at the beginning of November in order to build a cross country ski track. In 2006 two piles of snow, each with a volume of approximately $10,000 \mathrm{~m}^{3}$ were stored, insulated with a $70-80 \mathrm{~cm}$ thick layer of sawdust as shown in Table 1. Approximately $30 \%$ melted and $10 \%$ had turned into ice near the ground (Tidig och säker snö, 2007). Over the years, larger volumes of snow have been stored and the approximate volume of snow melt for piles with a volume of $20,000 \mathrm{~m}^{3}$ has been $20 \%$ (see Table 1). In 2015, the snow storage was placed beside the place where the previous piles of snow had been located, in order to let the ice layer on the ground melt. During the summer only $12 \%$ of the snow melted, which was assumed to be due to better drainage without the ice crust underneath the pile. In 2016, two piles of snow with a volume of $30,000 \mathrm{~m}^{3}$ in each pile were stored, covered with a $40 \mathrm{~cm}$ thick layer of sawdust. Since some sawdust is lost each year during the handling process, some new sawdust was added each year to the insulating layers on the piles. In 2014, eight years after the first snow was stored, all the old sawdust was replaced with new. No noticeable reduction in melt rate was however observed with the new sawdust compared to the old sawdust (Hedlund, 2016).

Snow has been stored twice in Piteå, Sweden, and used for cross country skiing (Lintzén, 2012; Lintzén, 2013). In 2012 about $2400 \mathrm{~m}^{3}$ of snow was stored and in 2013 the volume was about $3400 \mathrm{~m}^{3}$. The insulating material was geotextile and bark. The total snow melt was $29 \%$ for both piles.

Arjeplog in Sweden is an important place for the automotive industry due to testing activities in a cold climate and a long winter season. However, the automotive industry is also affected by climate change and the later arrival of snow early in the season. Therefore a snow storage experiment was done in 2013 in order to investigate if stored snow can be used for testing of tyres early in the season in case of a lack of natural snow. The results from the test showed that $61 \%$ of the snow melted.

At the Birkebeiner ski stadium in Norway wood chips are used as thermal insulation of snow (Rindal, 2016). In 2015 about 17\% of the initial volume melted during the summer. It has been noticed that a larger volume of snow melts when old wood chips are used. The wood chips are therefore replaced every third year.

In 2013, several piles of snow were stored in Sochi in Russia for the Olympic Games in 2014. The piles were covered with geotextile, foamed plastics and some piles were also covered with aluminum foil to reflect the sun (Martikainen, 2016). The geotextile blankets were made of several layers (Hoffert, 2013). A layer of thermal foam was added followed by a geotextile layer to render evaporation. The melting percentage varied between 20 and $50 \%$ for these piles.

Orsa Grönklitt and Högbo Bruk, Sweden, also use stored snow for cross country ski tracks, which are used by both amateurs and professional skiers early in the season. In Orsa Grönklitt, approximately $5000 \mathrm{~m}^{3}$ of snow is stored covered with a $40-50 \mathrm{~cm}$ thick layer of bark (Ädel, 2012). In Högbo, $8000 \mathrm{~m}^{3}$ of snow was stored during the summer of 2016, covered with sawdust (Rommedahl, 2016). The volume of melted snow has not been estimated at these two locations.

In Japan a $0.3 \mathrm{~m}$ thick layer of rice husks was used as insulation on a snow depot, which was found to decrease the melt rate significantly 
(Skogsberg, 2005). This shows that different kinds of agricultural waste also may be used as insulation on snow. Other materials like straw and sheep's wool are likely also applicable as thermal insulation (Skogsberg and Lundberg, 2005). However, mineral wool and other materials without capillary water transport will benefit from lower thermal conductivity but suffer from omitted evaporative cooling.

The results of debris or mineral particles as a thermal insulation on snow have been observed on glaciers and anthropogenic snow patches, where the melt rate decreases with thickness of the debris layer (Pelto, 2000; Kayastha et al., 2000; Takeuchi et al., 2000; Podolskiy et al., 2015). In contrast to wood chips, there is no decay of debris and thus a one-time cost, if chosen as thermal insulation on a snow depot (Skogsberg, 2005).

One advantage with granular materials as thermal insulation is the adjustment to the pile and its geometry as the snow melts. Loose sheets may slide apart as the pile changes in shape, which is one disadvantage with the sheets. Skogsberg (2005) stated other disadvantages with the loose sheets as being considered too small, too difficult to handle, too expensive and too fragile. However, the development has advanced and different kinds of loose sheets have been successfully used as thermal insulation, for example in Sochi, Russia, prior to the 2014 winter Olympics (Sonne, 2013) and in Idre, Sweden during the summer of 2016 (Skoglund, 2016).

Polystyrene, commonly known as Styrofoam, has been used as insulating material for snow storage. However, Styrofoam might not be a long lasting thermal insulating material due to poor weatherability (Gray, 2011). The thermal conductivity is similar to that of sawdust and cutter shavings, i.e. around $0.08 \mathrm{Wm}^{-1} \mathrm{~K}^{-1}$. The water transport capacity of polystyrene is not known but the water absorption is $0.03-1 \%$. This indicates some water transport capacity and perhaps also evaporation. Irregularly shaped polystyrene pieces allow space for air which is a favorable property of insulating materials.

The total melted volume as a percentage of the initial volume for the piles in Table 1, is shown in Fig. 4. The trend is that larger initial volumes result in relatively lower snow melt. However, it is important to point out that the properties and thickness of insulating materials were different for these piles.

\section{Practical experiments using sawdust and bark as insulating materials}

\subsection{Study of melting rate using different insulating materials}

Sawdust and bark are the two most commonly used insulating materials in Scandinavia. In order to compare the efficiency of these materials as thermal insulation for snow, an experiment was designed where the melt rate of piles with approximately equal volume were studied. Three piles of snow were used in the test;

- Pile 1 covered with bark,

- Pile 2 covered with sawdust,

- Pile 3 was left uncovered.

The experiment was carried out in Arjeplog, Sweden, during the summer of 2013. (The location of Arjeplog is latitude $66^{\circ} 03^{\prime} 06^{\prime \prime} \mathrm{N}$, longitude $17^{\circ} 53^{\prime} 09^{\prime \prime} \mathrm{E}$ at an elevation of $426 \mathrm{~m}$ above sea level.) Each pile was shaped like a chopped cone with approximately the following dimensions; base diameter, $12 \mathrm{~m}$, top diameter $6 \mathrm{~m}$ and height, $3 \mathrm{~m}$. Thus, the approximate volume of each pile was initially $200 \mathrm{~m}^{3}$. The piles were made of natural snow. The thickness of the insulating layer of sawdust varied in the range of $30-40 \mathrm{~cm}$ and the thickness of the insulating layer of bark was approximately $40 \mathrm{~cm}$. Both the sawdust and the bark originated from coniferous trees. The period of storage was between the 15th of April and the 8th of October 2013.

\subsection{Observation of melt rate for piles with different surface areas}

Surface melt is the major factor influencing the total melt rate (Skogsberg, 2005). To study melting rate due to surface area, two piles of snow with different geometry and surface areas were observed with respect to the melting rate. The volumes of the piles were different, but the same insulation was used. One pile, called Pile 4, consisted of natural snow collected in the area close to the place of storage. This pile was stored in Arjeplog, Sweden during the summer of 2013. Pile 5, consisted of snow collected from a downhill ski slope and was a mixture of natural snow and machine-made snow. Pile 5 was stored in Piteå, Sweden, during the same period of time as the pile in Arjeplog. The surfaces of both piles were covered with geotextile and an approximately $50-60 \mathrm{~cm}$ thick layer of bark.

The volume of each pile was measured using a position instrument, Topcon GR-S1, a handheld computer with built-in receiver and a PG-A1 antenna, a so called network RTK device, i.e., a differential GPS. The instrument is used for relative measurements, which means that it will get both positions directly from a satellite and corrections from a base station located at a known position. The base stations belong to the land surveying "Lantmäteriet". The volumes of the piles were measured at the beginning of the storage period, i.e. on the 15th of April, after about six weeks of storage and at the end of the storage period, on the 8th of October. The ground surface area of the piles was measured and the ratio between the ground surface area and the total volume was calculated. This gives an indication of the surface area, which was difficult to estimate due to the irregular shape of the piles.

Meteorological data were collected every fourth hour using weather stations situated close to the piles. The monthly average temperature in Arjeplog and Pitea during the study period is shown in Fig. 5. According to data from SMHI (Swedish Meteorological and Hydrological Institute) the temperature during this period was slightly higher than the average for these months.

\section{Theoretical calculations of melting rate}

Theoretical calculations of the snow melt were performed in order to compare calculated results to the practical experiment, Piles 1-3. A simplified model was used where the total melted volume, $V_{T O T}$, was calculated as the sum of the contributions from ground melt, $V_{\text {ground }}$, surface melt, $V_{\text {surface }}$ and rain melt, $V_{\text {rain }}$, i.e.

$V_{T O T}=V_{\text {ground }}+V_{\text {surface }}+V_{\text {rain }}$

The general heat equation without heat due to phase change can be written as

$\frac{\partial^{2} T}{\partial x^{2}}+\frac{\partial^{2} T}{\partial y^{2}}+\frac{\partial^{2} T}{\partial z^{2}}=\frac{c}{\lambda} \frac{\partial T}{\partial t}$

where, $T$ is the temperature (K), $\lambda$ is the coefficient of thermal conductivity $\left(\mathrm{W} \mathrm{m}^{-1} \mathrm{~K}^{-1}\right), c$ is the heat capacity $\left(\mathrm{J} \mathrm{kg}^{-1} \mathrm{~K}^{-1}\right)$ and $t$ is the time (s).

This equation constitutes the basis when calculating the loss by leakage to the ground.

\subsection{Ground melt}

The thermal flow from the ground, $Q_{\text {ground }}(\mathrm{W})$, can be calculated as

$Q_{\text {ground }}=\lambda_{\text {ground }} A_{\text {ground }} \frac{\Delta T_{g}}{l}$

where $\lambda_{\text {ground }}$ is the coefficient of thermal conductivity for the ground $\left(\mathrm{W} \mathrm{m}{ }^{-1} \mathrm{~K}^{-1}\right.$ ), $A_{\text {ground }}$ the area of the pile towards the ground $\left(\mathrm{m}^{2}\right), \Delta T_{g}$ the temperature difference $(\mathrm{K})$ between the ground surface and a distance, $l(\mathrm{~m})$, down in the ground (Johannesson and Bäckström, 2009).

The rate of melted snow from ground melt, $v_{\text {ground }}\left(\mathrm{m}^{3} \mathrm{~s}^{-1}\right)$, can thus be calculated as 


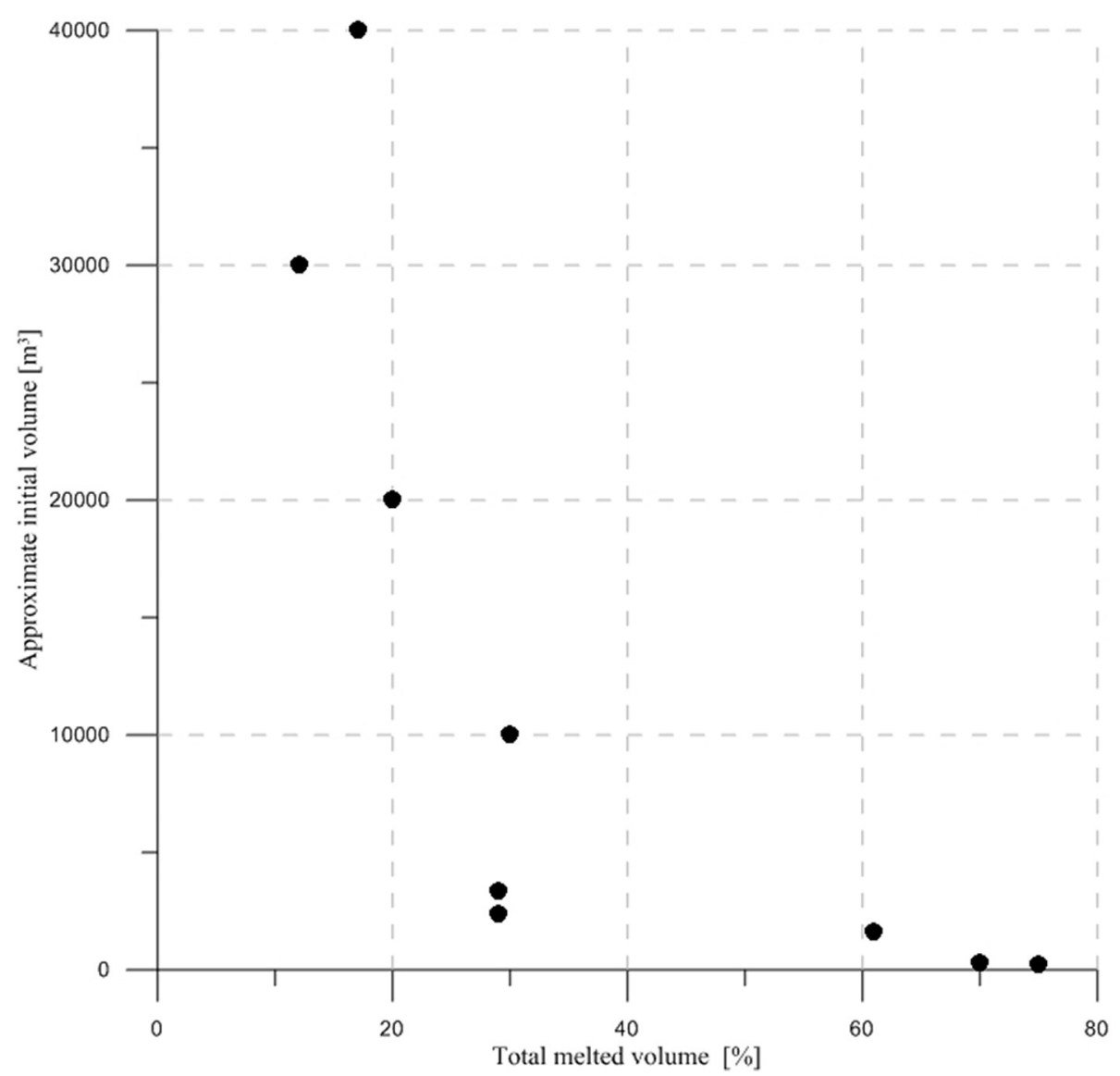

Fig. 4. Approximate initial volume versus the melted volume as a percentage for the piles in Table 1 and Table 2 .

$v_{\text {ground }}=\frac{Q_{\text {ground }}}{L_{\text {snow }} P_{\text {snow }}}$

where $L_{\text {snow }}\left(\mathrm{J} \mathrm{kg}^{-1}\right)$ is the latent heat of fusion for the snow and $\rho_{\text {snow }}$ is the density of the snow $\left(\mathrm{kg} \mathrm{m}^{-3}\right)$ (Näslund, 2000).

The total volume of melted snow due to ground melt, $V_{\text {ground }}\left(\mathrm{m}^{3}\right)$ is then

$V_{\text {ground }}=v_{\text {ground }} t$ where $t$ is the time (s) for the period of storage.

\subsection{Surface melt}

The melting rate with respect to the surroundings can be regarded as a stationary problem, with respect to the variations in air temperature (Näslund, 2000). The heat transport from the surroundings, $Q_{\text {surface }}$ (W) can be calculated as

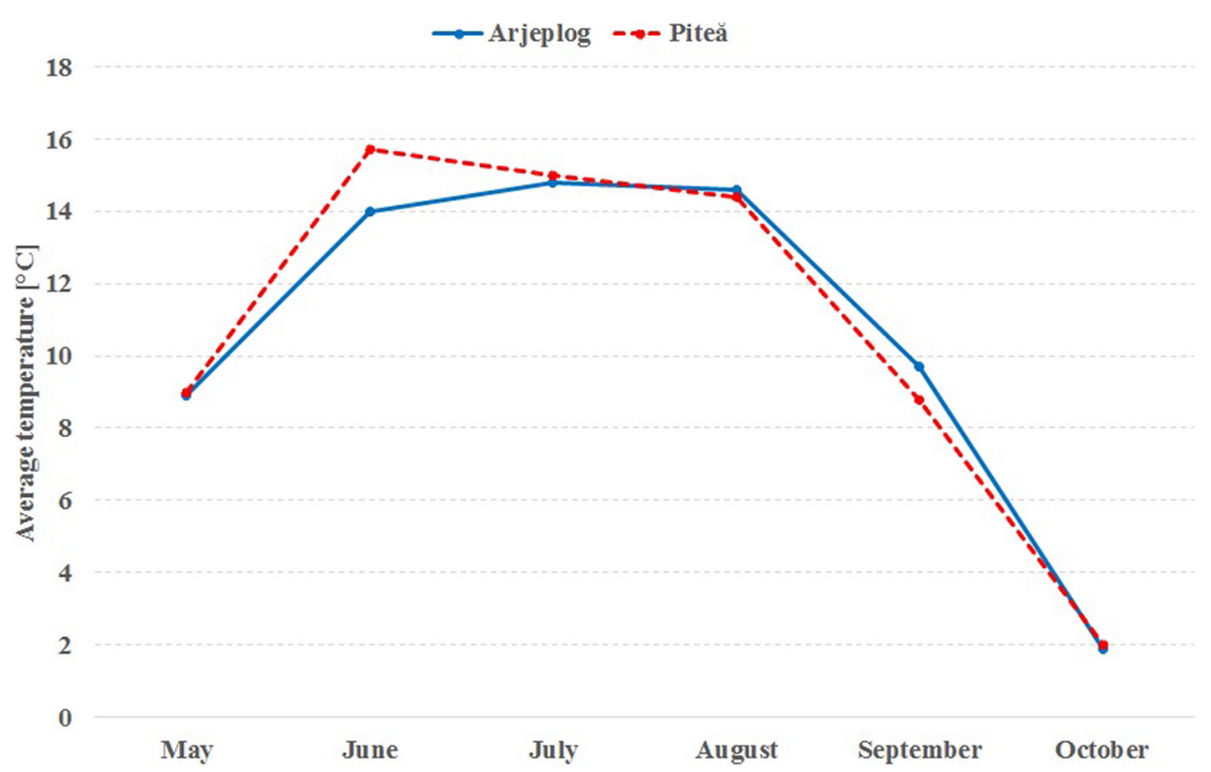

Fig. 5. Monthly average temperature $\left[{ }^{\circ} \mathrm{C}\right]$ in Arjeplog and Piteå, Sweden during the study period in 2013. 
$Q_{\text {surface }}=A_{\text {surface }} * \frac{\lambda_{i}}{d}\left(\Delta T_{S}\right)$

where $A_{\text {surface }}$ is the surface area $\left(\mathrm{m}^{2}\right)$ of the pile of snow, $\lambda_{i}$ is the coefficient of thermal conductivity for the insulating material (W $\mathrm{m}^{-1} \mathrm{~K}^{-1}$ ), $d$ is the thickness of the insulating material ( $\mathrm{m}$ ) and $\Delta T_{s}$ is the temperature difference $(\mathrm{K})$ between the air and the snow. Skogsberg (2001) estimated the coefficient of thermal conductivity for the insulating material to be the average value of the thermal conductivity for water and for the thermal conductivity of dry solid material, as the insulating material was assumed to be wet. The same estimation has been made in these calculations. The melt rate with respect to the surroundings, $v_{\text {surface }}\left(\mathrm{m}^{3} \mathrm{~s}^{-1}\right)$, can thus be calculated as

$v_{\text {surface }}=\frac{Q_{\text {surface }}}{\mathrm{L}_{\text {snow }} \rho_{\text {snow }}}$

The total melted volume due to surface melt, $V_{\text {surface }}\left(\mathrm{m}^{3}\right)$, is

$V_{\text {surface }}=v_{\text {surface }} t$

\subsection{Rain melt}

The volume of snow which melts through rain, $V_{\text {rain }}$, can be calculated as

$V_{\text {rain }}=\frac{P A \rho_{\text {water }} c_{\text {water }} T_{\text {surroundings }}}{L_{\text {snow }} \rho_{\text {snow }}}$

where $P$ is the amount of precipitation (m), $A$ is the total area of the pile $\left(\mathrm{m}^{2}\right), \rho_{\text {water }}$ is the density of water $\left(\mathrm{kg} \mathrm{m}^{-3}\right), c_{\text {water }}$ is the heat capacity of the water $\left(\mathrm{J} \mathrm{kg}^{-1} \mathrm{~K}^{-1}\right)$ and $T_{\text {surroundings }}$ is the air temperature (K) (Näslund, 2000).

\section{Results}

\subsection{Sawdust and bark as insulating material}

The volumes of the piles of snow stored in Arjeplog, including the approximately $70 \mathrm{~m}^{3}$ of bark and $60 \mathrm{~m}^{3}$ of sawdust are shown in Table 2. Due to technical problems with the instrument during the time for the second measurement (May, 27), no data was archived for the pile covered with sawdust at this date.

Pile 1 did not significantly change in volume between the first measurement in mid-April and the second measurement at the end of May, as shown in Table 2. At the time of the last measurement, 8th of October, $154 \mathrm{~m}^{3}$ of snow had melted in Pile 1 , which corresponds to $70 \%$. In Pile 2 the melted volume was $130 \mathrm{~m}^{3}$, corresponding to $75 \%$. The pile of snow without insulation melted away during the first month of storage.

\subsection{Melting rate of snow piles with different surface areas}

The volumes of the piles with different surface areas are shown in

Table 2

Snow storage experiment in Arjeplog, Sweden, in 2013 using sawdust and bark as insulating materials. The presented volumes include insulating material.

\begin{tabular}{|c|c|c|c|c|c|c|}
\hline \multirow[t]{2}{*}{ Date } & \multicolumn{2}{|c|}{$\begin{array}{l}\text { Pile 1: covered with } \\
\text { bark }\end{array}$} & \multicolumn{2}{|c|}{$\begin{array}{l}\text { Pile 2: covered with } \\
\text { sawdust }\end{array}$} & \multicolumn{2}{|c|}{ Pile 3: uncovered pile } \\
\hline & $\begin{array}{l}\text { Total } \\
\text { volume } \\
{\left[\mathrm{m}^{3}\right]}\end{array}$ & $\begin{array}{l}\text { Total } \\
\text { snow } \\
\text { melt } \\
{[\%]}\end{array}$ & $\begin{array}{l}\text { Total } \\
\text { volume } \\
{\left[\mathrm{m}^{3}\right]}\end{array}$ & $\begin{array}{l}\text { Total } \\
\text { snow } \\
\text { melt } \\
{[\%]}\end{array}$ & $\begin{array}{l}\text { Total } \\
\text { volume } \\
{\left[\mathrm{m}^{3}\right]}\end{array}$ & $\begin{array}{l}\text { Total } \\
\text { snow } \\
\text { melt [\%] }\end{array}$ \\
\hline April 15 & $290 \mathrm{~m}^{3}$ & & $234 \mathrm{~m}^{3}$ & & $190 \mathrm{~m}^{3}$ & \\
\hline May 27 & $278 \mathrm{~m}^{3}$ & 2 & - & & 0 & 100 \\
\hline October 8 & $136 \mathrm{~m}^{3}$ & 70 & $104 \mathrm{~m}^{3}$ & 75 & 0 & \\
\hline
\end{tabular}

Table 3

Snow storage in Arjeplog and Piteå in 2013. Volume of the piles and the relationship between the ground surface area and the total volume.

\begin{tabular}{llllll}
\hline & $\begin{array}{l}\text { Volume, } \\
\text { April, 15 } \\
{\left[\mathrm{m}^{3}\right]}\end{array}$ & $\begin{array}{l}\text { Volume, } \\
\text { October 8, } \\
{\left[\mathrm{m}^{3}\right]}\end{array}$ & $\begin{array}{l}\text { Ground } \\
\text { surface area, } \\
\text { October 8, } \\
{\left[\mathrm{m}^{2}\right]}\end{array}$ & $\begin{array}{l}\text { Ground } \\
\text { surface area/ } \\
\text { Total volume }\end{array}$ & $\begin{array}{l}\text { Total } \\
\text { snow } \\
\text { melt [\%] }\end{array}$ \\
\hline Pile 4 & 1590 & 614 & 803 & 1.3 & 61 \\
Pile 5 & 3409 & 2406 & 1284 & 0.5 & 29 \\
\hline
\end{tabular}

Table 3. The ground surface area at the end of the storage period, the ratio between the ground surface area and the total volume and the total snow melt as a percentage are also given. The ratio between the ground surface area and the total volume is an indication of the surface area, which was not measured, but is of interest for the snow melt.

The ratio between the ground surface area and the total volume was much larger for Pile 4 than for Pile 5, as shown in Table 3. Pile 4 was very widespread with a low height and correspondingly a large ground surface area and a large upper surface area. About $1000 \mathrm{~m}^{3}$ of snow melted in both piles which corresponds to a snow melt of $61 \%$ for Pile 4 and $29 \%$ for Pile 5 .

\subsection{Theoretical calculations of melting rate}

The different parts of the total melt rate were calculated according to the Eqs. (5), (8) and (9), using the values given in Table 4. The air temperature, i.e. the temperature of the surroundings was calculated as the average temperature during the period of snow storage. The temperature difference, $\Delta T_{g}$, between the ground surface and a distance of $2 \mathrm{~m}$ into the ground was assumed to be $275.15 \mathrm{~K}\left(+2{ }^{\circ} \mathrm{C}\right)$. Tabulated values of thermal conductivity for the ground, $\lambda_{\text {ground }}$, are between 0.15 and $2 \mathrm{Wm}^{-1} \mathrm{~K}^{-1}$ (Sundberg, 1988). In these calculations the value was estimated to $1 \mathrm{Wm}^{-1} \mathrm{~K}^{-1}$. Depending on the degree of compaction, the thermal conductivity for sawdust, $\lambda_{\text {sawdust, }}$ is between 0.08 and $0.14 \mathrm{Wm}^{-1} \mathrm{~K}^{-1}$ (Mörtstedt and Hellsten, 1999). The value used in the calculations was $0.1 \mathrm{Wm}^{-1} \mathrm{~K}^{-1}$. The value of the thermal conductivity for bark varies in literature. The value used for the calculations was $0.074 \mathrm{Wm}^{-1} \mathrm{~K}^{-1}$ (Bridgwater, 2008). The temperature of the snow was assumed to be $273.15 \mathrm{~K}\left(0^{\circ} \mathrm{C}\right)$. The precipitation during the period of storage was calculated based on data for Arjeplog from SMHI (Swedish Meteorological and Hydrological Institute).

The area of the piles was calculated according to the approximate dimensions of the piles, i.e. base diameter $12 \mathrm{~m}$, top diameter $6 \mathrm{~m}$ and height $3 \mathrm{~m}$. The average density of stored snow measured at samples from the snow storage in Östersund, Sweden was $590 \mathrm{~kg} \mathrm{~m}^{-3}$. Viklander (1994) found that the density of snow in a snow depot was

Table 4

Values of properties used to calculate the snow melt for test piles stored in Arjeplog during the summer of 2013.

\begin{tabular}{|c|c|}
\hline Quantity & Value \\
\hline$T_{\text {snow }}$ & $273.15 \mathrm{~K}$ \\
\hline$T_{\text {surroundings }}$ & $285.05 \mathrm{~K}$ \\
\hline$\rho_{\text {snow }}$ & 550,600 and $650 \mathrm{~kg} \mathrm{~m}^{-3}$ \\
\hline$\rho_{\text {water }}$ & $1000 \mathrm{~kg} \mathrm{~m}^{-3}$ \\
\hline$L_{\text {snow }}$ & $92.8 \mathrm{~J} \mathrm{~kg}^{-1} \mathrm{~K}^{-1}$ \\
\hline$c_{\text {water }}$ & $1.16 \mathrm{~J} \mathrm{~kg}^{-1} \mathrm{~K}^{-1}$ \\
\hline$\lambda_{\text {sawdust }}$ & $0.1 \mathrm{~W} \mathrm{~m}^{-1} \mathrm{~K}^{-1}$ \\
\hline$\lambda_{\text {bark }}$ & $0.074 \mathrm{~W} \mathrm{~m}^{-1} \mathrm{~K}^{-1}$ \\
\hline$\lambda_{\text {water }}$ & $0.58 \mathrm{~W} \mathrm{~m}^{-1} \mathrm{~K}^{-1}$ \\
\hline$\lambda_{\text {ground }}$ & $1 \mathrm{~W} \mathrm{~m}^{-1} \mathrm{~K}^{-1}$ \\
\hline$\Delta T_{g}$ & $275.15 \mathrm{~K}$ \\
\hline$\Delta T_{s}^{\circ}$ & $285.05 \mathrm{~K}$ \\
\hline$l$ & $2 \mathrm{~m}$ \\
\hline$P$ & $316 \mathrm{~mm}$ \\
\hline
\end{tabular}


Table 5

Results from theoretical calculations of melted snow for Pile 1 and Pile 2.

\begin{tabular}{|c|c|c|c|c|c|c|}
\hline & \multicolumn{2}{|c|}{ Density $550 \mathrm{~kg} \mathrm{~m}^{-3}$} & \multicolumn{2}{|c|}{ Density $600 \mathrm{~kg} \mathrm{~m}^{-3}$} & \multicolumn{2}{|c|}{ Density $650 \mathrm{~kg} \mathrm{~m}^{-3}$} \\
\hline & $\begin{array}{l}\text { Melted volume } \\
{\left[\mathrm{m}^{3}\right]}\end{array}$ & $\begin{array}{l}\text { Melted volume in \% } \\
\text { of } \mathrm{V}_{\text {TOT }}\end{array}$ & $\begin{array}{l}\text { Melted volume } \\
{\left[\mathrm{m}^{3}\right]}\end{array}$ & $\begin{array}{l}\text { Melted volume in } \% \\
\text { of } \mathrm{V}_{\text {тот }}\end{array}$ & $\begin{array}{l}\text { Melted volume } \\
{\left[\mathrm{m}^{3}\right]}\end{array}$ & $\begin{array}{l}\text { Melted volume in \% of } \\
\mathrm{V}_{\text {TOT }}\end{array}$ \\
\hline \multicolumn{7}{|l|}{ Pile 1: Covered with bark } \\
\hline Ground melt, $v_{\text {ground }}$ & 9 & 6 & 8 & 6 & 8 & 7 \\
\hline Surface melt, $\mathrm{v}_{\text {surface }}$ & 117 & 82 & 107 & 82 & 99 & 81 \\
\hline Rain melt, $\mathrm{v}_{\text {rain }}$ & 17 & 12 & 16 & 12 & 15 & 12 \\
\hline Total calculated snow melt, $\mathrm{V}_{\text {Tот }}$ & $143 \mathrm{~m}^{3}$ & & $131 \mathrm{~m}^{3}$ & & $122 \mathrm{~m}^{3}$ & \\
\hline $\begin{array}{l}\text { Total snow melt in percent based on } \\
\text { calculated values: }\end{array}$ & $72 \%$ & & $66 \%$ & & $61 \%$ & \\
\hline \multicolumn{7}{|l|}{ Pile 2: Covered with sawdust } \\
\hline Ground melt, $v_{\text {ground }}$ & 9 & 6 & 8 & 5 & 8 & 6 \\
\hline Surface melt, $\mathrm{v}_{\text {surface }}$ & 135 & 84 & 124 & 84 & 115 & 83 \\
\hline Rain melt, $\mathrm{v}_{\text {rain }}$ & 17 & 10 & 16 & 11 & 15 & 11 \\
\hline Total calculated snow melt, $\mathrm{V}_{\mathrm{TOT}}$ & $161 \mathrm{~m}^{3}$ & & $148 \mathrm{~m}^{3}$ & & $138 \mathrm{~m}^{3}$ & \\
\hline $\begin{array}{l}\text { Total snow melt in percent based on } \\
\text { calculated values: }\end{array}$ & $81 \%$ & & $74 \%$ & & $69 \%$ & \\
\hline
\end{tabular}

$650 \mathrm{~kg} \mathrm{~m}^{-3}$. Reasonable densities for stored snow are assumed to be between 550 and $650 \mathrm{~kg} \mathrm{~m}^{-3}$, which are the densities used for the theoretical calculations.

The results from the calculations of snow melt from the ground, rain and surface are given in Table 5. The calculated total melted volumes range between 122 and $143 \mathrm{~m}^{3}$ for Pile 1 , which corresponds to $61-72 \%$. Corresponding values for Pile 2 are between 138 and $161 \mathrm{~m}^{3}$ or $69-81 \%$, depending on the given density. The reduction of the areas of the piles with time has not been taken into account in the calculations, which should lead to overestimated calculated values.

As shown in Table 5, the calculated amount of snow that melted due to rain and ground melt was between 16 and 19\%. Rain and ground melt were found to contribute to less than $20 \%$ of the total natural melt when a $30,000 \mathrm{~m}^{3}$ pile of snow in Sundsvall, Sweden was covered with a $0.2 \mathrm{~m}$ thick layer of wood chips (Skogsberg and Nordell, 2001). The size of the piles in this study was substantially smaller though and the geometry different than for the pile in Sundsvall, but there is still a good agreement showing that about $20 \%$ of the total volume of melted snow likely is due to rain and heat from the ground.

The measured value of melted snow for Pile 1 (covered with bark) was $154 \mathrm{~m}^{3}$, corresponding to $70 \%$ of the initial volume. The measured value of melted snow for Pile 2 (covered with sawdust) was $130 \mathrm{~m}^{3}$, corresponding to $75 \%$. This shows that the measured values of melted snow are close to the calculated values.

\section{Discussion}

The results showed that the measured volume of melted snow as a percentage was slightly larger, $75 \%$, for Pile 2 covered with sawdust, compared to $70 \%$ for Pile 1 covered with bark. The initial volumes of snow in Pile 1 and Pile 2 were approximately $220 \mathrm{~m}^{3}$ and $174 \mathrm{~m}^{3}$ respectively.

The calculated values of the snow melt for Pile 1 and Pile 2, correspond well to the actual measured melted volumes of snow melt, although the area reduction was not taken into consideration in the calculations. The results indicate that the melt rate can be estimated with theoretical calculations, if the geometry of the pile is known and relevant data for climate and material properties are used. By calculating the snow melt, it is possible to estimate the effectiveness of different insulating materials and also the thickness required to sufficiently insulate the snow from melting. This gives an opportunity to make economic optimizations based on the amount of snow that melts and additional costs for insulation and placement.

As observed during the study of melt rate for Pile 4 and Pile 5, a bigger ratio between ground surface area and total volume results in a larger melt rate. It has been observed for instance in Östersund, that piles of snow with a larger volume lose less snow in percentage terms than piles with a smaller volume. The same trend was observed in Fig. 4, where the initial volumes versus snow melt expressed as percentages for the piles in this study are shown. The reason for this can be related to the surface melt rate. We assume that the heat and mass transfer through the surface is proportional to the surface area. For simplicity this fact is illustrated by modelling a pile of snow as a half sphere with radius $r$, the volume, $V_{r}$, of the pile will be

$V_{r}=\frac{2 \pi r^{3}}{3}$

and the surface area, $S_{r}$

$S_{r}=2 \pi r^{2}$

If a half sphere with radius, $r / 2$ is also modelled, the volume of this pile will be

$V_{\frac{r}{2}}=\frac{2 \pi r^{3}}{3 * 8}=\frac{V_{r}}{8}$

and the surface area

$S_{\frac{r}{2}}=\frac{2 \pi r^{2}}{4}=\frac{S_{r}}{4}$

According to Eq. 12, eight half spheres with radius $r / 2$ are required in order to get the same volume as one half sphere with radius $r$. The total surface area of eight half spheres of radius $r / 2$ is according to Eq. 13 , twice as large as the surface area of a half sphere with radius $r$. This means that it is advantageous to store snow in one large pile rather than in several smaller piles. Of course, any other modelling of the pile (e.g., chopped cones, etc.) could have been used as well, with a similar clear theoretical explanation of this fact. A minimized surface area implies steeper sides of a cone which should be kept in mind when designing the snow storage. The insulating material may fall off if it is placed on a pile with sides which are too steep.

Yet another reason for the greater percentage of snow melt for Pile 4 might be that this pile consisted of natural snow, which is known to be less weather resistant than machine made snow (Rixen et al., 2003, 2004 and others). This fact is however, not investigated. Future studies of using natural snow for snow storage are recommended, as well as comparing the difference in the quality of natural and machine-made snow after the period of storage.

Hedlund (2016) and others have reported a considerable reduction of the volume of the piles occurring in the summer when the relative humidity increases to above $70-80 \%$. The volume reduction between the first and the second measurement of Pile 1 was negligible, as seen in 


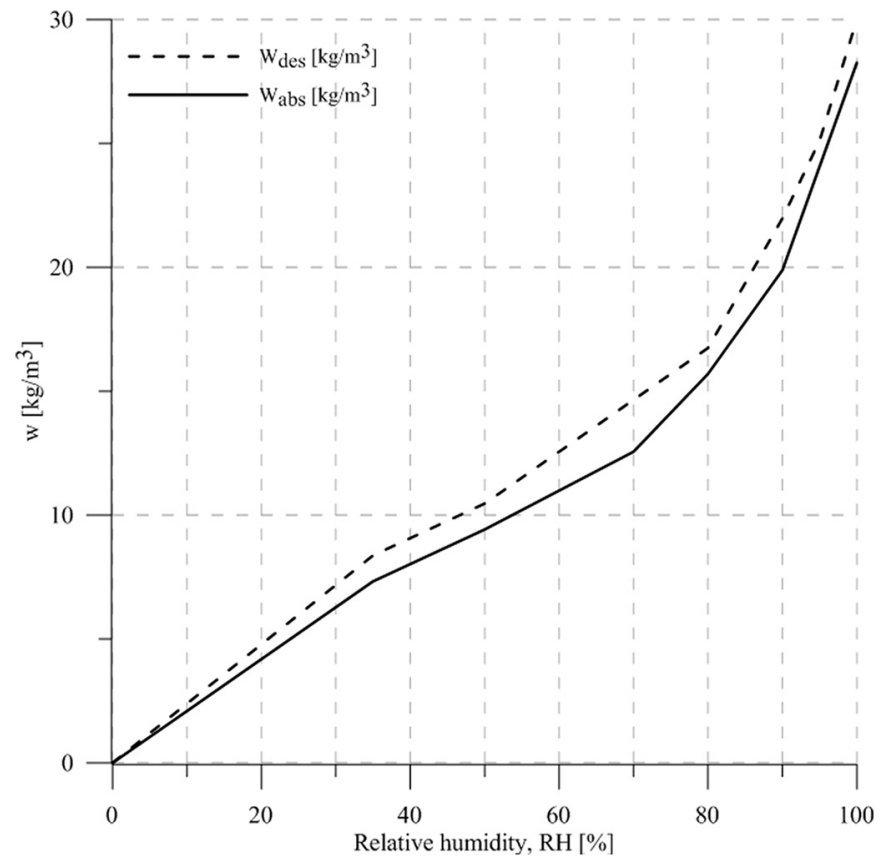

Fig. 6. Sorption isotherms for cutter shavings with dry density $90 \mathrm{~kg} \mathrm{~m}^{-3}$ based on Swedish spruce with dry density $430 \mathrm{~kg} \mathrm{~m}^{-3}$ (after Hedenblad, 1996 and Skogsberg, 2005).

Table 2 (only $12 \mathrm{~m}^{3}$ or $2 \%$ difference in volume), which also shows that the melt rate increases during the latter part of the summer. An increase in air humidity impairs the evaporation in the insulating layer. Skogsberg and Lundberg (2005) found that the evaporative cooling effect had a significant influence on the melt rate, which seems to be the case also in this study. A porous material in humid air with constant relative humidity and constant temperature will eventually reach its hygroscopic equilibrium moisture content (Skogsberg, 2005). Increasing hygroscopic moisture content is called absorption, whereas decreasing is called desorption. Sorption isotherms for cutter shavings with a dry density of $90 \mathrm{~kg} \mathrm{~m}^{-3}$ based on spruce with a dry density of $430 \mathrm{~kg} \mathrm{~m}^{-3}$ are shown in Fig. 6 . The moisture content, $w$, is shown as a function of relative air humidity, $R H$. The moisture content during absorption is denoted $\mathrm{w}_{\mathrm{abs}}\left(\mathrm{kg} \mathrm{m}^{-3}\right)$ and the moisture content during desorption is denoted $\mathrm{w}_{\mathrm{des}}\left(\mathrm{kg} \mathrm{m}^{-3}\right)$. The moisture content increases rapidly as the relative humidity exceeds approximately $85-90 \%$. An increase in relative humidity is hence a reason for increased melt rate. The relative humidity in Arjeplog generally increases from a monthly average of around $60 \%$ in May to around $85 \%$ in October according to data from SMHI, Swedish Meteorological and Hydrological institute.

An insulating layer without or with poor evaporation will likely lead to an increased melt rate. It is therefore believed to be advantageous to choose a thermal insulating material with good evaporation properties. The evaporative properties of different insulting materials and the influence on the melt rate is a subject for future studies.

The decay rate of insulating materials is mentioned in previous sections and explains why the material is replaced after a certain time. The exact decay rate of different commonly used insulating materials has not been studied but is suggested to be investigated in future studies. The moisture in porous materials is transferred as vapour and as water. In an insulated snow depot most of the melt water is transported downwards through the snow, but some of it is transported upwards through the insulating layer due to capillary forces and evaporation. The rate at which moisture is transferred in the insulating layer is denoted, $\dot{m}$, and can be calculated using Fick's law and is in one dimension written as the product of a transfer coefficient and a potential gradient (Hedenblad, 1996; Skogsberg, 2005). The moisture transfer due to evaporation in the insulating layer can thus be written as: $\dot{m}_{\text {diff }}=-\delta_{\text {vap }} \nabla v=-\frac{D}{\mu_{p o r}} \frac{d v}{d x}$

where, $\dot{m}_{\text {diff }}$ is the diffusive vapour flow rate $\left(\mathrm{kg} \mathrm{m}^{-2} \mathrm{~s}^{-1}\right), \delta_{v a p}$ is the vapour permeability coefficient $\left(\mathrm{m}^{2} \mathrm{~s}^{-1}\right), \nabla v$ is the vapour content gradient $\left(\mathrm{kg} \mathrm{m}^{-3} \mathrm{~m}^{-1}\right), D$ is the vapour diffusivity in air $\left(\mathrm{m}^{2} \mathrm{~s}^{-1}\right), \mu_{\text {por }}$ is the resistance coefficient, $d v$ the vapour content difference $\left(\mathrm{kg} \mathrm{m}^{-3}\right)$ and $d x$ the distance over which the vapour content difference occurs (m). The rate at which moisture is transferred in the insulating layer will decrease with time and with capillary height, resulting in an increased melt rate of the snow. A wet porous material being drained will attain a new moisture gradient through the material, called the passive capillary moisture content, where both total moisture content and capillary height are greater than before soaking (Nevander and Elmarsson, 1994). The capillary moisture transfer rate, $\dot{m}_{c a p}$.

$\left(\mathrm{kg} \mathrm{m}^{-2}\right)$ can according to Skogsberg (2005) be written as:

$\dot{m}_{\text {cap }}=\frac{A}{2 \sqrt{t}}$

where $A$ is the water sorption coefficient $\left(\mathrm{kg} \mathrm{m}^{-2} \mathrm{~s}^{-1 / 2}\right)$ and $t$ is the time the material has been in contact with water. The coefficient $A$ decreases towards zero with time. The decay rate with time with respect to the capillary moisture transfer is shown in Fig. 7, showing that the capillary moisture flow has been reduced to about half the initial value after approximately two years.

The factors influencing the degradation of moisture-transfer properties of the insulating material should be taken into account in order to insulate the snow sufficiently. Adding some new material or increasing the layer thickness might be alternatives to replacing all the insulating material.

Calculations of heat capacity for different insulating materials, $\lambda_{\text {ins }}$, were done according to a method described in Andersland and Ladanyi (2004). The thermal resistance, $R\left(\mathrm{~m}^{2} \mathrm{~K} \mathrm{~W}^{-1}\right)$ was then calculated as the the ratio between the thickness of the insulating layer, $d(\mathrm{~m})$, and the thermal conductivity, $\lambda_{\text {ins }}\left(\mathrm{W} \mathrm{m}^{-1} \mathrm{~K}^{-1}\right)$, i.e.

$R=\frac{d}{\lambda_{\text {ins }}}$

The thermal conductivity is not very sensitive to the porosity if the degree of water saturation is high. However, the thickness of the insulating layer is of high importance for the melt rate. The mouldering of bark results in a decreased porosity and hence a reduced thickness of the insulating layer. Moreover, a reduced porosity impairs the evaporation which in turn will lead to poorer cooling of the pile.

Assuming a unit volume of insulating material, $V$ consisting of the sum of the volume of solid particles, $\mathrm{V}_{\mathrm{s}}$ and the volume of the pores, $V_{p}$, then the relationship between the total volume and the porosity, $n$, is:

$V=V_{s}+V_{P}=V_{s}\left(\frac{1}{1-n}\right)$

The volume of the insulating layer decreases linearly with decreasing void ratio. The porosity for sawdust and bark has not been investigated, but low mouldered peat has a porosity of between 0.91 and 0.96 , intermediate peat has a porosity in the range of $0.89-0.94$ and high mouldered peat has values in the range of $0.88-0.93$, according to Vesterberg et al. (2016). A similar trend is expected for bark and sawdust, which also have degrading insulating properties with time. Sawdust with a moisture content above $16 \%$ contains micro-organisms, which thus imply a deterioration of the material with time (Wiberg and Morén, 1999).

The thermal resistance as a function of porosity, $n$, is shown in Fig. 8. The thermal resistance decreases with decreasing porosity. The porosity decreases as a consequence of ageing and mouldering which thus leads to deteriorating insulating properties.

To create an optimal snow depot, the most important factor is to minimize the surface melt rate, since this constitutes the largest part of 


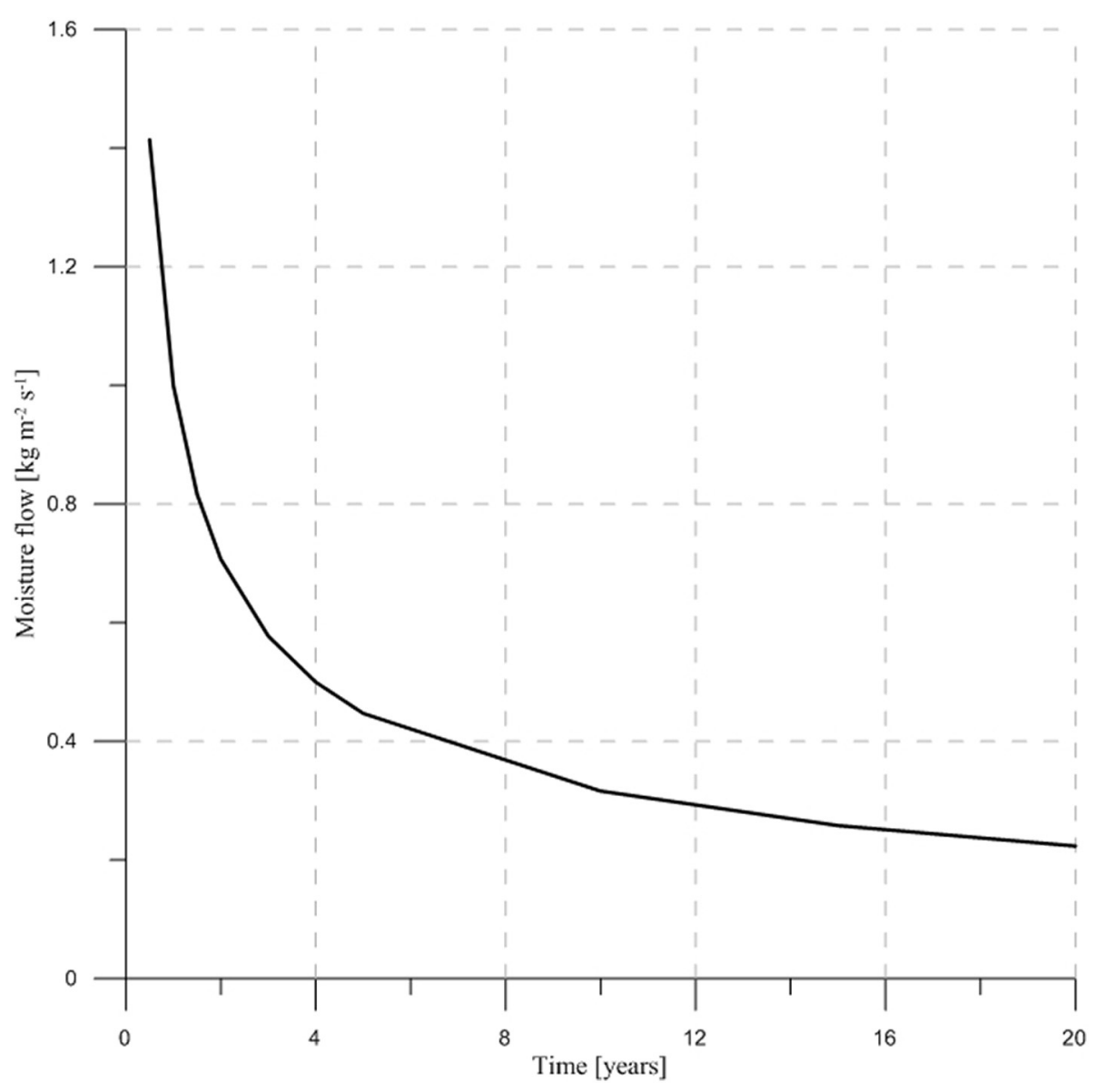

Fig. 7. Moisture flow into a porous material in contact with water.

the total melt rate. The geometry should be designed to minimize the surface area. Cost and properties of different insulating material should be taken into consideration. Depending on the local conditions different alternatives may be preferred. Skogsberg and Lundberg (2005) concluded that enough thermal insulation is only a matter of layer thickness. Thus, an insulating layer with poor porosity can be compensated by increasing the thickness instead. The snow storage should be placed at a location which is protected from wind and solar radiation, with good drainage. It has been observed that snow in large snow depots has turned into ice near the ground surface (Hedlund, 2016). This might be a result of poor drainage but also relate to snow compaction due to settlement, which caused an increase of density. Therefore, there might be an upper limit for the recommended height of a pile, which should be further investigated in future studies.

The efficiency of different thermal insulating materials needs to be further investigated, both when it comes to natural materials and fabricated materials. Fabricated materials can be new types of textiles, which both serve as insulation for the snow whilst also enabling evaporation to minimize the snow melt. Moreover, the long-term profitability should be taken into account. Materials with degrading properties need to be replaced after some years whereas others have a longer lifespan. In addition, some materials are more environmentally harmful than others. The decay rate of different insulating materials is a question for future investigations.

\section{Conclusions}

Based on the observations, mainly from Scandinavian snow storages and field experiments in Sweden, a set of practical recommendations for insulated snow depots can be made as follows:
- Natural materials such as bark and different types of cutter shavings are efficient thermal insulating materials for snow depots, if the layer thickness is sufficient.

- The surface melt constitutes the most significant part, around $80 \%$, of the total snow melt in an insulated snow depot. Thus, the surface area should be minimized.

Theoretical calculations with chopped cones showed that approximately $80 \%$ of the total melted volume was due to surface melt, $15 \%$ was due to rain melt and 5\% was due to ground melt.

- The modelling and theoretical calculations presented in this paper give a good basis for estimating the melt rate and melted volume of stored snow.

- Higher relative humidity and higher moisture content in the insulating layer will increase the melt rate of stored snow. Decreased evaporation implies increased melt rate.

- The thermal resistance will decrease with time when sawdust and bark are used as insulating materials. This is due to ageing and mouldering, which imply a decreased porosity.

For effective snow storage it is suggested to further investigate questions of upper limit on pile heights and different insulating materials and their degradation with time.

\section{Acknowledgements}

The author wants to thank Icemakers and Piteå Skidallians for help with the snow storage experiments and Luleå University of Technology for financial support. Moreover, many thanks to Professor Lars-Erik Persson for his generous advice. 


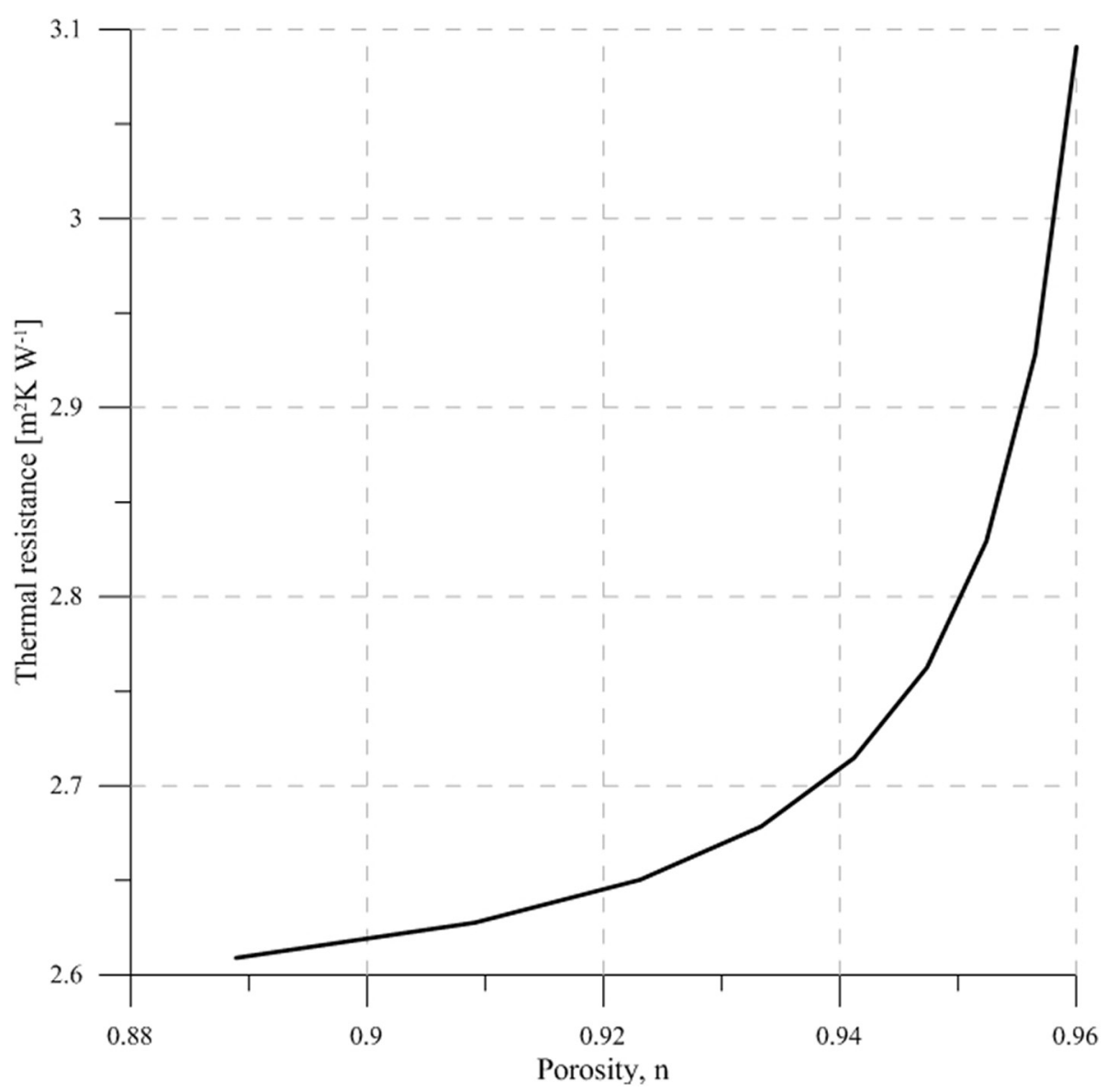

Fig. 8. Thermal resistivity as a function of porosity for an insulating layer.

\section{References}

Ädel, P., 2012. Private Communication.

Andersland, O.B., Ladanyi, B., 2004. Frozen Ground Engineering, Second edition. John Wiley \& Sons.

Bridgwater, A., 2008. Progress in Thermochemical Biomass Conversion. John Wiley \& Sons.

Gray, J.E., 2011. Polystyrene: Properties, Performance and Applications, First edition. Nova Science Publishers, Inc, New York, pp. 123-124.

Hedenblad, G., 1996. Materialdata för fukttransportberäkningar (Material Data for Moisture Flow Calculations). T19:1996. Byggforskningsrådet, Stockholm, Sweden. Hedlund, R., 2016. Private Communication.

Hoffert, J., 2013. Three ways tech could come to rescue in case of warm weather for the 2014 Sochi Winter Olympics. https://www.sporttechie.com.

Johannesson, D., Bäckström, J., 2009. Snökylning av Norrmejerier. Umeå University.

Kayastha, R.B., Takeuchi, Y., Nakawo, M., Ageta, Y., 2000. Practical Prediction of Ice Melting Beneath Various Thickness of Debris Cover on Khumbu Glacier, Nepal, Using a Positive Degree-Day Factor. Iahs Publication, pp. 71-82.

Kumar, V., Hewage, K., Haider, H., Sadiq, R., 2016. Techno-economic performance evaluation of building cooling systems: a study of snow storage and conventional chiller systems. Cold Reg. Sci. Technol. 130 (2016), 8-20.

Lintzén, N., 2012. Snow storage in Piteå 2012. In: Internal Report. Luleå University of Technology.

Lintzén, N., 2013. Snow storage in Arjeplog and Piteå 2013. In: Internal Report. Luleå University of Technology.

Martikainen, M., 2016. Private Communication.

Mörtstedt, S., Hellsten, G., 1999. Data och diagram: energi-och kemitekniska tabeller. Esselte studium.

Näslund, M., 2000. Fjärrkyla i Sundsvall baserad på sjövatten och lagrad snö. Luleå University of Technology (Report 2000:132, ISSN: 1402-1617, ISRN: LTU-EX-00/ 132-SE).

Nevander, L.-E., Elmarsson, B., 1994. Fukthandbok - praktik och teori. AB Svensk Byggtjänst, Andra utgåvan. (ISBN 91-7332-716-6).

Nordell, B., Skogsberg, K., 2002. Snow and Ice Storage for Cooling Applications, Winter Cities. pp. 1-9. https://www.diva-portal.org/smash/get/diva2:1011643/ FULLTEXT01.pdf.

Nordell, B., Skogsberg, K., 2007. The Sundsvall snow storage - six years of operation. In: Thermal Energy Storage for Sustainable Energy Consumption: Fundamentals, Case Studies and Design. 234. pp. 349.

Olefs, M., Fischer, A., 2008. Comparative study of technical measures to reduce snow and ice ablation in Alpine glacier ski resorts. Cold Reg. Sci. Technol. 52 (2008), 371-384.
Pelkonen, J., 2013. Private Communication.

Pelto, M.S., 2000. Mass Balance of Adjacent Debris-Covered and Clean Glacier Ice in the North Cascades, Washington. vol. 264. Iahs Publication, pp. 35-42 (2000).

Podolskiy, E.A., Lobkina, V.A., Gensiorovsky, Y.V., Thibert, E., 2015. Evaluating ablation and environmental impact of giant anthropogenic snow patches (Yuzhno-Sakhalinsk, Russia). Cold Reg. Sci. Technol. 114 (2015), 44-60.

Rindal, H., 2016. Private Communication.

Rixen, C., Stoeckli, V., Ammann, W., 2003. Does artificial snow production affect soil and vegetation of ski pistes? A review. Perspect. Plant Ecol. Evol. Syst. 5 (4), 219-230.

Rixen, C., Haeberli, W., Stoeckli, V., 2004. Ground Temperatures under Ski Pistes with Artificial and Natural Snow. Arct. Antarct. Alp. Res. 36 (4), 419-427.

Rommedahl, O., 2016. Private Communication.

Skoglund, K., 2016. Private Communication.

Skogsberg, K., 2001. Seasonal Snow Storage for Cooling Applications. Luleå University of Technology (Licentiate Thesis 2001:51, ISSN: 1402-1757, ISRN: LTU-LIC-01/ 51-SE).

Skogsberg, K., 2005. Seasonal Snow Storage for Space and Process Cooling. Luleå University of Technology (Doctoral Thesis, 2005:30, ISSN:1402-1544, ISRN: LTUDT-05/30-SE).

Skogsberg, K., Lundberg, A., 2005. Wood chips as thermal insulation of snow. Cold Reg. Sci. Technol. 43 (3), 207-218.

Skogsberg, K., Nordell, B., 2001. The Sundsvall hospital snow storage. Cold Reg. Sci. Technol. 32 (1), 63-70.

Sonne, P., 2013. Olympic Task: Making Sure There's Snow. Wall Street Journal (14 December).

Sundberg, J., 1988. Thermal Properties of Soils and Rocks. Publ. A57. Institution of geology, Chalmers university of technology \& University of Gothenburg (ISSN: 03482367).

Takeuchi, Y., Kayastha, R.B., Nakawo, M., 2000. Characteristics of Ablation and Heat Balance in Debris-Free and Debris-Covered Areas on Khumbu Glacier. Iahs Publication, Nepal Himalayas, pp. 53-62 in the pre-monsoon season.

Tidig och säker snö, 2007. Project Report. Östersunds kommun (2007-10-01, DNR.2672006).

Vesterberg, B., Carlsten, P., Lindh, P., 2016. Erfarenhet av byggmetoder på torvmark. SIG Publikation 26, Statens geotekniska institut.

Viklander, M., 1994. Melting of Urban Snow Deposits: A Water Quality Study. Luleå University of Technology, 1994-19 (Licentiate Thesis, ISBN: 0280-8242).

Wiberg, P., Morén, P.J., 1999. Moisture flux determination in wood during drying above fibre saturation point using CT-scanning and digital image processing. Holz ans Rohund Werkstoff 57 (2), 137-144. 